\title{
Arterial hypertension in the elderly accompanied in primary care: profile and associated factors ${ }^{a}$
}

\author{
Hipertensão arterial em idosos acompanhados na atenção primária: perfil e fatores associados \\ Hipertensión arterial en ancianos acompañados en la atención primaria: perfil y factores asociados
}

Breno de Sousa Santana ${ }^{1}$ (C)

Bárbara Soares Rodrigues ${ }^{1}$ (D)

Marina Morato Stival ${ }^{1}$ (D)

Cris Renata Grou Volpe ${ }^{1}$ (D)

1. Universidade de Brasília. Brasília, DF, Brasil

\begin{abstract}
Objective: to analyze blood pressure control in elderly hypertensives accompanied by a Basic Health Unit of the Federal District, determining the sociodemographic profile and the associated risk factors. Method: this is a cross-sectional study with 133 elderly hypertensive patients. Variables related to sociodemographic factors, life habits, clinical factors and adherence to drug therapy were evaluated through the application of semistructured instruments and validated scales. Results with $p<0.05$ were considered significant. Results: the elderly presented controlled blood pressure $(56.4 \%)$ predominantly. The majority of the participants were female and women also had a higher rate of uncontrolled blood pressure (86.2\%). Older age was associated with higher blood pressure values $(p=0.031)$. Alcoholism $(p=0.020)$ and mean body mass index of $33.0(p<0.000)$ were factors associated with hypertension adherence to therapy had more controlled values of systolic and diastolic blood pressure. Conclusion and implications for the practice: it was verified that there is a strong association between the risk factors discussed and the lack of control of the blood pressure of elderly hypertensive, especially with regard to advanced age, alcoholism, obesity and overweight, and it is necessary to reorient the planning and strategies of promotion of health and prevention of diseases directed at the elderly hypertensive in the scope of primary health care.
\end{abstract}

Keywords: High Blood Pressure; Risk Factors; Health Promotion; Primary Health Care; Public Health Nursing.

\section{Resumo}

Objetivo: Analisar o controle da pressão arterial de idosos hipertensos acompanhados por uma Unidade Básica de Saúde do Distrito Federal, determinando o perfil sociodemográfico e os fatores de risco associados. Método: Trata-se de um estudo transversal realizado com 133 idosos hipertensos. Foram avaliadas variáveis relacionadas aos fatores sociodemográficos, hábitos de vida, fatores clínicos e adesão à terapêutica medicamentosa através da aplicação de instrumentos semiestruturados e escalas validadas. Resultados com $p<0,05$ foram considerados significativos. Resultados: Os idosos apresentaram pressão arterial controlada $(56,4 \%)$ de forma predominante. A maioria dos participantes foi do sexo feminino e as mulheres também apresentaram maior taxa de descontrole ( $86,2 \%)$. A idade avançada mostrou associação com maiores valores pressóricos $(\mathrm{p}=0,031)$ Alcoolismo ( $p=0,020)$ e índice de massa corporal médio de $33,0(p<0,000)$ foram fatores associados com a hipertensão arterial. Conclusão e implicações para a prática: Verificou-se que existe forte associação entre os fatores de risco abordados e a falta de controle da pressão arterial de idosos hipertensos, principalmente no que diz respeito à idade avançada, alcoolismo, obesidade e sobrepeso, sendo necessário reorientar o planejamento e as estratégias de promoção da saúde e prevenção de agravos, voltadas a idosos hipertensos no âmbito da atenção primária à saúde.

Palavras-chave:Pressão Arterial Alta; Fatores de risco; Promoção da Saúde; Atenção Primária à Saúde; Enfermagem em Saúde Comunitária.

\section{Resumen}

Objetivo: analizar el control de la presión arterial en ancianos hipertensos acompañados por una Unidad Básica de Salud del Distrito Federal, determinando el perfil sociodemográfico y los factores de riesgo asociados. Método: se trata de un estudio transversal realizado con 133 ancianos hipertensos. Se evaluaron variables relacionadas a los factores sociodemográficos, hábitos de vida, factores clínicos y la adhesión a la terapéutica medicamentosa, a través de la aplicación de instrumentos semiestructurados y escalas validadas. Los resultados con $p<0,05$ se consideraron significativos. Resultados: los ancianos presentaron presión arterial controlada $(56,4 \%)$ de forma predominante. La mayoría de los participantes fue del sexo femenino y las mujeres también presentaron mayor tasa de descontrol $(86,2 \%)$. La edad avanzada mostró asociación con mayores valores de presión ( $p=0,031)$. El etilismo $(p=0,020)$ y el índice de masa corporal promedio de $33,0(p<0,000)$ fueron factores asociados a la hipertensión arterial. Conclusión e implicaciones para la práctica: se constató que existe una fuerte asociación entre los factores de riesgo abordados y la falta de control de la presión arterial de los ancianos hipertensos, principalmente en lo que se refiere a la edad avanzada, al alcoholismo, a la obesidad y al sobrepeso, siendo necesario reorientar la planificación y las estrategias de promoción de la salud y prevención de agravios, dirigidos a ancianos hipertensos en el ámbito de la atención primaria de la salud.

Palabras clave: Presión Arterial Alta; Factores de Riesgo; Promoción de la Salud; Atención Primaria de la Salud; Enfermería en Salud Comunitaria. 


\section{INTRODUCTION}

The aging of the Brazilian population is a fact that is linked to urbanization, social and economic changes and globalization, affecting how people live, work and feed. As a result, the incidence of obesity and physical sedentary lifestyle has increased, important risk factors for chronic non-communicable diseases (NCDs). ${ }^{1}$ In Brazil, these diseases constitute a serious public health problem, corresponding to $68.3 \%$ of death causes, especially cardiovascular diseases. ${ }^{2,3}$

Approximately 66 million people report chronic diseases in Brazil, being the Southeast, with 29.5 million individuals, the Brazilian region where CNCD are the most prevalent diseases, with more than a third of the national rate. In the Midwest, on the other hand, the number of individuals is lower, with 4.7 million people reported with chronic diseases, 817 thousand of them in the Federal District, ${ }^{4}$ the location of this study.

Important NDC, arterial hypertension (HT) is a condition characterized by elevation and sustentation of blood pressure (BP) levels. Generally, dyslipidemia, abdominal obesity and diabetes mellitus (DM) are risk factors for this condition. Inadequate $\mathrm{BP}$ control is directly related to stroke (STRK), acute myocardial infarction (AMI), heart failure (HF) and chronic kidney disease (CKD), serious events that reduce longevity and quality of life, implying declining global functionality, especially the elderly. ${ }^{5}$

Due to the changes because of aging, such as morphological, metabolic and psychic alterations, elderly individuals are at higher risk for developing arterial hypertension, which may be considered the most prevalent condition in the elderly attended by Basic Health Units (BHU). ${ }^{6}$ Facing this, the Brazilian Ministry of Health (MS) implemented a care line for elderly, called "Strategies for promoting healthy aging", in order to qualify care for this population and reorganize health services, in special attention to Primary Health Care (PHC). ${ }^{7}$

It is worth highlighting the importance of nursing in $\mathrm{PHC}$, with functions that range from the management and maintenance of UBS functioning to actions directed at individuals, families and community, in order to guarantee integral assistance, health promotion and protection and disease prevention, including in the monitoring and control of HT in elderly individuals. ${ }^{8}$

Estimates show a prevalence of $35.8 \%$ of HT among Brazilians, with men being the majority. ${ }^{9}$ The Brazilian Society of Cardiology listed the main risk factors for $\mathrm{HT}$, being: age, sex and ethnicity, overweight and obesity, high salt intake, alcoholism, sedentary lifestyle, socioeconomic factors and genetics, ${ }^{5}$ being essential that, in addition to the treatment, the modifiable factors are also reversed for BP control. ${ }^{10}$

The individual cost of a chronic disease is high and is usually associated with work and productivity loss, and other factors that negatively influence household income, with an estimated \$4.18 billion in treatment costs from 2006 to 2015 and that cardiovascular diseases, whose $\mathrm{HT}$ is a risk factor, are those that generate or require the highest expenses related to hospital admissions and procedures of medium and high complexity. ${ }^{4}$

It is imperative to invest in prevention and control of blood pressure values of hypertensive elderly, since knowing this population profile can help in the construction of public policies and in the reduction of HT disorders. Based on this context, the aim of this study was to analyze the blood pressure control of hypertensive elderly accompanied by a Basic Health Unit of the Federal District, determining the sociodemographic profile and the associated risk factors.

\section{METHODS}

It is a cross-sectional study carried out in a Basic Health Unit in the Federal District from January to July 2017. The study population consisted of hypertensive participants referenced in this unit. The sample was from convenience and formed by 133 elderly hypertensive patients' participants. Individuals with continuous blood pressure values $\geq 140 \mathrm{mmHg}$ for systolic blood pressure (SBP) and $\geq 90 \mathrm{mmHg}$ for diastolic blood pressure (DBP) were considered hypertensive. ${ }^{5}$

Individuals with 60 years of age or older, diagnosed with Arterial Hypertension for at least 3 months and who participated in the follow-up group to hypertensive patients adopted at the unit were eligible. Patients with mental illness, neoplasms under treatment, and those participants who did not complete any of the instruments applied or whose instruments could not be interpreted due to illegible handwriting, erasure and duplicity of answers were excluded.

For the data collection it was used: (a) a semi-structured instrument to determine the socio-demographic and socioeconomic profile, (b) a semi-structured instrument on the use of medicines in general, (c) instrument on quality of life and physical activity, (d) instrument for assessing nutritional status and body composition, and e) modified scale of adherence to treatments - Morisky-Green test. ${ }^{11}$

For the analysis of the biochemical and immunological parameters, $15 \mathrm{~mL}$ of blood were collected in the antecubital vein using vacuum tubes with the participant in a 12-hour fast for the determination of total cholesterol and triglycerides. To measure the body mass, a Filizola $\circledR$ scale with accuracy of 100 $\mathrm{g}$ was used; regarding the stature, a vertical metric scale with accuracy of $1 \mathrm{~mm}$ was used.

The body composition was evaluated using the Dual Energy X-Ray Absorptiometry (DEXA) with equipment of the General Electric-GE® brand, model 8548 BX1L, year 2005, Lunar DPX type, with software Encore Program 2005. The examination was performed by a trained technician. For carrying out the procedure, all participants removed their metal belongings (bracelets, earrings, rings, engagement rings, etc.), moved to a supine position on the equipment table, so that they were completely centralized in comparison with the sides of the table. The parti- 
cipants were instructed to extend their lower limbs, and a Velcro tape was used to keep them close and support the feet, so that they were at an angle of approximately $45^{\circ}$ to the vertical plane. The upper limbs remained extended and positioned along the body, without contact with the trunk.

The BP measurement was performed by auscultatory technique, after 10 minutes of rest, in a calm environment, with the participant seated, with the legs uncrossed, feet resting on the floor, back resting on the chair, relaxed and silent.

From the data collected, we divided the participants into two groups: 1) individuals with controlled BP (Controlled BP) and 2) individuals with uncontrolled BP (Uncontrolled BP). Next, we listed the researched variables that are risk factors for uncontrolled blood pressure and consequent positive influencers for the prevalence of Hypertension.

The following variables were analyzed: sex, marital status, occupation, age, income, schooling, smoking, alcoholism, sedentary lifestyle, time of diagnosis of hypertension, Body Mass Index (BMI), Body Fat Percentage (BFP), total cholesterol, triglycerides, SBP and DBP values, and adherence to drug therapy. High BMI was considered to be a value above 24.9 for overweight and 29.9 for obesity. ${ }^{12}$ The values considered abnormal for total cholesterol and triglycerides were $>190 \mathrm{mg} / \mathrm{dL}$ and $>150 \mathrm{mg} /$ $\mathrm{dL}$, respectively. ${ }^{13}$

Data were organized in spreadsheets of Microsoft Exce/ ${ }^{\circledR}$ 2016 and analyzed using IBM Package for the Social Sciences $\left(S P S S^{\circledR}\right.$ ) version 20.0. The statistical tests used were Pearson's Chi-Square and $t$-Student. Logistic regression was used to determine the independent effect of association between independent variables and uncontrolled blood pressure. For the preparation of the final model, multivariate logistic regression was used, including study variables using the foward stepwise method. The odds ratio (OR) was estimated, with a significance level of $5 \%$ and a $95 \%$ confidence interval.

All participants were informed about the risks and benefits of the research and that the results were used as the basis of the scientific work. They were ensured anonymity and their privacy was preserved by replacing their names with identification numbers, which were included in the data collection instruments. They were told that they could refuse to participate in the study when they deemed it appropriate, with no personal loss. They signed a Free and Informed Consent (FIC). This study was submitted to the Ethics and Research Committee (CEP) of the Foundation for Teaching and Research in Health Sciences of the Federal District State Health Department (FEPECS/SES-DF), pursuant to Resolution 466/2012 of the National Health Council (CNS), approved on December 8, 2015 according to opinion number 1.355.211 and CAEE 0367215.5.0000.5553.

\section{RESULTS}

The mean age of the study participants was $63.2 \pm 10.5$ years, with a predominance of those with controlled BP $(56.4 \%)$, mean income of $\mathrm{R} \$ 1,729.00 \pm 1,549.00$, with emphasis on married $(49.62 \%)$ and retirees $(41.4 \%)$. It is possible to note that women, who were also the majority $(87.2 \%)$, had a higher rate of uncontrolled blood pressure (86.2\%) when compared to men. The mean schooling level observed was $6.9 \pm 3.9$ years (Table 1 ).

There was a predominance of non-smokers (94\%), non-alcoholics (91.73\%) and non-sedentary individuals (81.9\%), curiously without significant association with blood pressure control (Table 2). Participants the highest average disease time presented uncontrolled BP the (127.9 \pm 98.5 months). High BMI (33.0 \pm 6.0$)$ showed significant relation with uncontrolled blood pressure. Accordingly, uncontrolled blood pressure is associated with higher BFP average (43.8 \pm 8.2$)$, total cholesterol $(203,2 \pm 41,8)$ and triglycerides $(165,3 \pm 80,3)$, without much statistical relevance. In both groups, a moderate adherence to drug therapy was predominated, with an important but not significant relation between adherence and control of blood pressure levels (Table 3).

After multivariate logistic regression were applied, the variables were adjusted according to their association with non-control of blood pressure, eliminating the confounding variables. As verified, individuals with uncontrolled BP are more likely to be older than those with controlled BP. Accordingly, individuals with uncontrolled PA have a higher chance of presenting high $\mathrm{BMI}$, alcoholism, and higher values of SBP and DBP in relation to those who maintain adequate BP control, as shown in Table 4.

\section{DISCUSSION}

This study analyzed the factors that influence uncontrolled blood pressure in hypertensive elderly patients monitored in a Primary Care Facility in the Federal District. In order to do so, sociodemographic factors and life habits, clinical factors, and the characterization of SBP and DBP were investigated and, finally, the factors associated with uncontrolled of BP were listed according to logistic regression.

A study included a sample of 124 hypertensive patients followed by a Brazilian UBS, of whom $65.3 \%$ had uncontrolled BP, a higher percentage when compared to the $43.6 \%$ of hypertensive patients who composed the sample of 133 participants. This study also shows that the majority of participants with uncontrolled BP are female,${ }^{14}$ which is consisted with the results obtained. Another study from 2016 with 190 hypertensive female elderly participants showed that $43.2 \%$ of them had uncontrolled BP. ${ }^{15}$

In the United States, the rate of blood pressure control indicated by the study was $52.8 \%,{ }^{16}$ whereas in Europe the control rate was $51.2 \%$ to $65.4 \%,{ }^{17}$ values similar to the $56.4 \%$ evidenced here. In Ghana, on the other hand, a study showed unsatisfactory control of $33.3 \%$ among the participants previously diagnosed with $\mathrm{HT}$, whereas among those without a previous diagnosis, approximately $70 \%$ presented pre-hypertensive and hypertensive stages. ${ }^{18}$ This evaluation cannot be established, since all participants in our study had previous hypertension. 
Table 1. Sociodemographic factors associated to blood pressure control in the elderly. Brasília, Distrito Federal, Brazil, 2017.

\begin{tabular}{|c|c|c|c|c|c|c|}
\hline & & \multicolumn{2}{|c|}{ Controlled BP } & \multicolumn{2}{|c|}{ Uncontrolled BP } & \multirow[b]{2}{*}{$\mathbf{P}$} \\
\hline & & $\mathbf{N}$ & $\%$ & $\mathbf{N}$ & $\%$ & \\
\hline Characteristics & $N(\%)=133$ & 75 & 56.4 & 58 & 43.6 & \\
\hline Gender & & & & & & 0.463 \\
\hline Female & $116(87.2)$ & 66 & 88 & 50 & 86.2 & \\
\hline Male & $17(12.8)$ & 9 & 12 & 8 & 13.8 & \\
\hline Marital Status & & & & & & 0.644 \\
\hline Single & $20(15.04)$ & 10 & 13.3 & 10 & 17.3 & \\
\hline Married & $66(49.62)$ & 37 & 49.3 & 29 & 50 & \\
\hline Divorced & $10(7.52)$ & 5 & 6.7 & 5 & 8.6 & \\
\hline Widower/widow & $37(27.82)$ & 23 & 30.7 & 14 & 24.1 & \\
\hline Occupation & & & & & & 0.798 \\
\hline Active & $29(21.8)$ & 13 & 17.3 & 16 & 27.6 & \\
\hline Retired & 55 (41.4) & 32 & 42.7 & 23 & 39.6 & \\
\hline Inactive & $49(36.8)$ & 30 & 40 & 19 & 32.8 & \\
\hline Age $(M \pm S D) *$ & $63.2 \pm 10.5$ & & & & & 0.031 \\
\hline Income $(\mathrm{M} \pm \mathrm{SD})$ ** & $1,729.00 \pm 1,549.00$ & 1,61 & 57.00 & 1,87 & 9.00 & 0.368 \\
\hline Education $(\mathrm{M} \pm \mathrm{SD})$ * & $6.9 \pm 3.9$ & & & & & 0.198 \\
\hline
\end{tabular}

Table 2. Life habits and their association with the arterial pressure control of the elderly. Brasília, Distrito Federal, Brazil, 2017.

\begin{tabular}{|c|c|c|c|c|c|c|}
\hline & & \multicolumn{2}{|c|}{ Controlled BP } & \multicolumn{2}{|c|}{ Uncontrolled BP } & \multirow[b]{2}{*}{$\mathbf{P}$} \\
\hline & & $\mathbf{N}$ & $\%$ & $\mathbf{N}$ & $\%$ & \\
\hline Characteristics & $N(\%)=133$ & 75 & 56.4 & 58 & 43.6 & \\
\hline Smoking & & & & & & 0.540 \\
\hline Yes & $8(6)$ & 5 & 6.7 & 3 & 5.2 & \\
\hline No & 125 (94) & 70 & 93.3 & 55 & 94.8 & \\
\hline Alcoholism & & & & & & 0.175 \\
\hline Yes & $11(8.27)$ & 8 & 10.7 & 3 & 5.2 & \\
\hline No & 122 (91.73) & 67 & 89.3 & 55 & 94.8 & \\
\hline Sedentarism & & & & & & 0.997 \\
\hline Yes & $24(18.05)$ & 13 & 17.3 & 11 & 19 & \\
\hline No & 109 (81.95) & 62 & 82.7 & 47 & 81 & \\
\hline
\end{tabular}

The sample verified in this study was composed of $87.2 \%$ of women, where $43.1 \%$ had uncontrolled BP, which further reiterates the estimates. A study with a larger sample was conducted in Brazil. In 2015, with 15,105 hypertensive patients. ${ }^{9}$ In it, the prevalence of $\mathrm{HT}$ was higher among men than among women. Based on this scenario, we can infer that hypertension is not conditioned to sex. Both men and women have similar rates of $\mathrm{HT}$, as well as uncontrolled BP.

Some structural and physical changes are caused by aging, among them changes in the cardiovascular system. In women, the climacteric and menopause alterations, such as arterial stiffness, may be responsible for the prevalence of $\mathrm{HT}$ in the 
Table 3. Clinical factors, characterization of SBP and DBP, adherence to drug therapy and its association with the arterial pressure control of the elderly. Brasília, Distrito Federal, Brazil, 2017.

\begin{tabular}{|c|c|c|c|c|}
\hline & & Controlled BP & Uncontrolled BP & \\
\hline & & $\mathbf{N}$ & $\mathbf{N}$ & $\mathbf{P}$ \\
\hline Characteristics & $N(\%)=133$ & $75(56.4)$ & $58(43.6)$ & \\
\hline Diagnosis of $\mathrm{HT}(\mathrm{M} \pm \mathrm{SD}) *$ & $122.0 \pm 92.8$ & $117.5 \pm 88.6$ & $127.9 \pm 98.5$ & 0.152 \\
\hline BMI (M $\pm S D)$ & $31.4 \pm 5.5$ & $30.2 \pm 4.9$ & $33.0 \pm 6.0$ & 0.006 \\
\hline 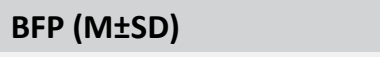 & $42.4 \pm 8.0$ & $41.1 \pm 7.6$ & $43.8 \pm 8.2$ & 0.085 \\
\hline Total cholesterol $(\mathrm{M} \pm \mathrm{SD})$ & $199.8 \pm 39.0$ & $197.5 \pm 37.1$ & $203.2 \pm 41.8$ & 0.451 \\
\hline Triglycerides (M $\pm S D)$ & $162.1 \pm 77.2$ & $159.9 \pm 75.6$ & $165.3 \pm 80.3$ & 0.786 \\
\hline $\mathrm{SBP}(\mathrm{M} \pm \mathrm{SD}) * *$ & $133.8 \pm 17.6$ & $121.6 \pm 8.8$ & $150.1 \pm 12.3$ & $<0.000$ \\
\hline $\mathrm{DBP}(\mathrm{M} \pm \mathrm{SD})^{* *}$ & $78.2 \pm 10.4$ & $74.5 \pm 7.4$ & $83.1 \pm 11.7$ & $<0.000$ \\
\hline Adherence & & & & 0.138 \\
\hline Low & 28 & $12(16)$ & $16(27.6)$ & \\
\hline Moderate & 63 & $37(49.3)$ & $26(44.8)$ & \\
\hline High & 42 & $26(34.7)$ & $16(27.6)$ & \\
\hline
\end{tabular}

Table 4. Associated factors with non-control of arterial pressure in the elderly after multivariate logistic regression analysis. Brasília, Distrito Federal, Brazil, 2017.

\begin{tabular}{llll}
\hline Factors & OR & IC & P \\
\hline Advanced age & 2.14 & $1.77-5.15$ & 0.040 \\
\hline Alcoholism & 1.32 & $1.03-1.94$ & 0.020 \\
\hline High PAS & 1.55 & $1.09-2.65$ & $<0.000$ \\
\hline High PAD & 1.99 & $1.70-2.70$ & $<0.000$ \\
\hline High BMI & 1.70 & $1.52-2.79$ & $<0.000$ \\
\hline Female Sex & 1.15 & $0.90-1.44$ & 0.266 \\
\hline Low income & 0.63 & $0.27-2.30$ & 0.410 \\
\hline Low education level & 0.88 & $0.38-1.99$ & 0.154 \\
\hline High PGC & 0.82 & $0.66-1.36$ & 0.756 \\
\hline High Total Cholesterol & 1.43 & $0.82-2.44$ & 0.108 \\
\hline High Triglycerides & 0.98 & $0.61-1.44$ & 0.688 \\
\hline Smoking & 0.78 & $0.55-1.32$ & 0.754 \\
\hline Sedentarism & 1.27 & $0.73-2.13$ & 0.395 \\
\hline
\end{tabular}

OR: Odds ratio; HF: 95\% confidence interval; PAS: Systolic Blood Pressure; BMI: Body mass index; PAD: Dyastolic Blood Pressure; BFP: Percent Body Fat

elderly. ${ }^{20}$ Studies also showed an intrinsic relationship between age and the uncontrolled blood pressure..$^{10,19}$

It is possible to note that high alcohol consumption is associated with elevated levels of SBP and DBP, as well as increased cholesterol levels and BMI values. These effects are important factors that lead to damage to the cardiovascular system, which can lead to hypertension. ${ }^{20}$
The average BMI for individuals with uncontrolled blood pressure was $33.0 \pm 6.0$, higher than the average identified in a similar study conducted in Portugal in 2017 with 709 individuals, where the average was $30.03 \pm 4.95 .{ }^{21}$ Another study also correlates a higher value of $\mathrm{BMI}$ with uncontrolled $\mathrm{BP}^{22}$

The Brazilian Association for the Study of Obesity and Metabolic Syndrome indicates that high BMI values are associated 
with rates of arterial hypertension and other cardiovascular diseases, however, it points out that the waist-height ratio is a better predictor for cardiometabolic risk factors in both sexes and suggests the use of this one. ${ }^{12}$

The rate of therapeutic adherence in a study of 231 participants was $19.7 \%$. Of the non-adherents, $33.2 \%$ had average adherence and $47.1 \%$ had low therapeutic adherence. Those participants with higher adherence rate had average BP values of $125.5 \times 85.3 \mathrm{mmHg}{ }^{23}$ The benefits of adherence to treatment are needed to establish relation and promote appropriate treatment. ${ }^{24,25}$ Comparing with the results obtained, participants with low adherence have higher rates of uncontrolled BP, and they have higher average of SBP and DBP. Thus, it can be verified that low adherence to therapy is an important risk factor for uncontrolled blood pressure.

The high cost of purchasing antihypertensive drugs, the use of different combinations of pharmacological classes and too many tablets are predictive factors for non-adherence. Non-adherence to costs has been surpassed in Brazil by free access to pharmacotherapy in an outpatient clinic level promoted by SUS. ${ }^{26}$ The use of polypills with a combination of different active ingredients is indicated as a viable strategy to improve compliance with drug treatment, ${ }^{27}$ which can be adopted by the public health system as a tool to improve BP control.

It is worth mentioning that hypertensive individuals present a great cost to the health system. It is estimated that the annual cost for treatment of hypertension in the public health system is $\mathrm{R} \$ 398.9$ million, representing $1.43 \%$ of SUS' total expenditures. $\mathrm{HT}$ is a potential clinical predictor for aggravation, longer length of hospital stay, and higher treatment cost. ${ }^{28}$

A study carried out in a Reference Unit of medium complexity in Recife, financed by SUS, presented the amounts paid in Reais for the procedures carried out within one year. Cardiology exams cost $\mathrm{R} \$ 223.8$ thousand, and $34.2 \%$ of them were diagnostic procedures. For clinical procedures, an appointment in cardiology had a cost of $R \$ 167.100$. The cost of cardiovascular and hypertension drugs was $\mathrm{R} \$ 1.95$ million, representing $24.6 \%$ of all expenses. ${ }^{29}$

In a study with data from 2008 to 2012 within the scope of SUS revealed 4.125 hospital admissions for cardiovascular diseases, corresponding to an average of 825 hospitalizations per year. Together with neoplasias, cardiovascular diseases represented the most expensive class, with an absolute total cost of $R \$ 12,600$, of which $51.2 \%$ were SUS' hospitalization costs. ${ }^{30}$

Recent comparison of the population of Latin America with other parts of the world shows that hypertension is a common risk factor for cardiovascular disease, which makes it essential to know the local epidemiological patterns of hypertension. ${ }^{31}$

Through a successful strategy of the Brazilian Society of Cardiology, a registry of the current clinical practice for the treatment of $\mathrm{HT}$ in Brazil was carried out and also pointed out that better knowledge about the way in which the control and the treatment of hypertensive occurs, as well as studies that show the characteristics of the Brazilian population, will allow the implementation of policies aimed at improving this procedure and, thus, contribute to a change in the epidemiological profile and decrease of cardiovascular morbidity and mortality in Brazil. ${ }^{32}$

Like this research, most of the studies found in the literature for the topic "hypertension and blood pressure control" were carried out in Basic Health Care Facilities and Family Health Facilities. The importance of Primary Care in this context is verified, since prevention and promotion can avoid complications due to chronic non-communicable diseases, such as hypertension. ${ }^{15,33,34}$

UBS, where data from this study were collected, has an organized support program for hypertensive individuals, with professionals having a great bound with patients, which may be justification for some variables that were not statistically significant and did not appear as risk factors. The nursing team is highly qualified and invests heavily in prevention and health education, as well as self-care.

It is important to take interdisciplinary actions that contribute to the management and control of hypertension and other cardiovascular diseases. The groups are tools that can complement the actions promoted by healthcare practitioners, enabling patients to share experiences and experience knowledge and practices, assisting in the treatment. ${ }^{34}$

Some of the variations found between this and other studies may be due to methodological differences. The cross-sectional design of this study is limited in the interpretation of the results, since it does not enable establishment of causal or temporal relationships, making it difficult to know if the factors are a consequence of the disease or preceded its occurrence. The use of BMI as one of the variables rather than the waist-to-height ratio was also an adverse factor. However, the results were positive, since they showed characteristics specific of the population studied and demonstrated the importance of a qualified health system, with the primary care considered the gateway to the network.

\section{CONCLUSION AND IMPLICATIONS FOR PRACTICE}

This study provided an analysis of blood pressure control and associated risk factors. We also draw the socio-demographic profile of the study participants. It was verified that there is a strong association between the risk factors approached and the lack of control of the blood pressure of hypertensive elderly, mainly with respect to advanced age, consumption of alcoholic beverage, obesity and overweight, according to BMI values.

In revisiting this context, nursing emerges as the profession that deals directly and consistently with the elderly population in primary care, especially in the Family Health Strategy model, adopted nationally. To carry out a survey of the sociodemographic and clinical profile of the elderly is an effective tool for the care 
practice, regarding the monitoring and control of arterial hypertension and is a differential in the care of the elderly hypertensive, since it allows planning and implementation of specific actions against the risk factors, preventing the progression of $\mathrm{HT}$ to more severe conditions.

The contributions of this study to the knowledge about arterial hypertension in elderly population are worth to be highlighted, although the design does not make possible the generalization of the findings. It is recommended to reorient the planning and strategies of health promotion and prevention of grievance aimed at the elderly hypertensive in the scope of primary health care, which presents great resolving power as a gateway to the system.

\section{FINANCIAL SUPPORT}

Support Research Foundation of the Federal District -FAPDF with funding from the research project "Approach of chronic non-communicable diseases in primary health care", process number 193.001.267/2016, coordinated by Dr. Marina Morato Stival and University of Brasília - UnB, as executing institution.

\section{REFERENCES}

1. Miranda GMD, Mendes ACG, Silva ALA. Population aging in Brazil: current and future social challenges and consequences. Rev Bras Geriatr Gerontol [Internet]. 2016 May/Jun;19(3):507-19. Available from: http://dx.doi.org/10.1590/1809-98232016019.150140

2. Ministério da Saúde (BR). Secretaria de Vigilância em Saúde, Departamento de Vigilância de Doenças e Agravos Não Transmissíveis e Promoção da Saúde. Vigitel Brasil 2017: vigilância de fatores de risco e proteção para doenças crônicas por inquérito telefônico: estimativas sobre frequência e distribuição sociodemográfica de fatores de risco e proteção para doenças crônicas nas capitais dos 26 estados brasileiros e no Distrito Federal em 2017. Brasília (DF). Ministério da Saúde; 2018 [Internet]. Available from: http://bvsms.saude.gov.br/bvs/ publicacoes/vigitel_brasil_2017_vigilancia_fatores_risco_1ed_rev.pdf

3. Ministério da Saúde (BR). Secretaria de Vigilância em Saúde, Departamento de Análise de Situação de Saúde. Plano de ações estratégicas para o enfrentamento das Doenças Crônicas Não Transmissíveis (DCNT) no Brasil 2011-2022. 1st ed. Vol. 1. Brasília (DF): Ministério da Saúde; 2011. [Internet]. 160 p. Available from: http://bvsms.saude.gov.br/bvs/publicacoes/plano_acoes_enfrent_ dent_2011.pdf

4. Malta DC, Stopa SR, Szwarcwald CL, Gomes NL, Silva Júnior JB, Reis AAC. Surveillance and monitoring of major chronic diseases in Brazil - National Health Survey, 2013. Rev Bras Epidemiol [Internet]. 2015 Dec;18(Suppl 2):3-16. Available from: http://dx.doi.org/10.1590/19805497201500060002

5. Malachias MVB, Souza WKSB, Plavnik FL, Rodrigues CIS, Brandão AA, Neves MFT, et al.; Sociedade Brasileira de Cardiologia, Sociedade Brasileira de Hipertensão, Sociedade Brasileira de Nefrologia. 7a Diretriz Brasileira de Hipertensão Arterial. Arq Bras Cardiol [Internet]. 2016 ;107(3Supl.3):1-83. Available from: http://publicacoes.cardiol. br/2014/diretrizes/2016/05_HIPERTENSAO_ARTERIAL.pdf

6. Andrade AO, Aguiar MIF, Almeida PC, Chaves ES, Araújo NVSS, Freitas Neto JB. Prevalence of arterial hypertension and associated factors in the elderly. Rev Bras Promoç Saúde [Internet]. 2014 Jul/ Sep;27(3):303-11. Available from: https://periodicos.unifor.br/RBPS/ article/view/2729/pdf
7. Ministério da Saúde (BR). Ministério da Saúde lança estratégia para promoção do envelhecimento saudável. Brasília (DF): Ministério da Saúde ; 2017 [Internet]. Available from: http://portalarquivos2.saude. gov.br/images/PDF/2017/novembro/06/06-11-2017-Saude-do-Idoso. pdf

8. Ferreira SRS, Périco LAD, Dias VRFG. The complexity of the work of nurses in Primary Health Care. Rev Bras Enferm [Internet] 2018;71(Suppl 1):704-9. Available from: http://dx.doi.org/10.1590/00347167-2017-0471

9. Chor D, Pinho Ribeiro AL, Sá Carvalho M, Duncan BB, Andrade Lotufo $P$, Araújo Nobre A, et al. Prevalence, awareness, treatment and influence of socioeconomic variables on control of high blood pressure: Results of the ELSA-Brasil study. PLoS One [Internet]. 2015;10(6):e0127382. Available from: https://doi.org/10.1371/journal.pone.0127382

10. Menanga A, Edie S, Nkoke C, Boombhi J, Musa AJ, Mfeukeu LK, et al. Factors associated with blood pressure control amongst adults with hypertension in Yaounde, Cameroon: a cross-sectional study. Cardiovasc Diagn Ther [Internet]. 2016 Oct;6(5):439-45. Available from: http://dx.doi. org/10.21037/cdt.2016.04.03

11. Ben AJ, Neumann CR, Mengue SS. Teste de Morisky-Green e Brief Medication Questionnaire para avaliar adesão a medicamentos. Rev Saúde Pública [Internet]. 2012 Apr;46(2):279-89. Available from: http:// dx.doi.org/10.1590/S0034-89102012005000013

12. Associação Brasileira para o Estudo da Obesidade e da Síndrome Metabólica (ABESO). Diretrizes Brasileiras de Obesidade 2016. 4a ed. São Paulo: ABESO; 2016. 188 p. [Internet]. Available from: http://www. abeso.org.br/uploads/downloads/92/57fccc403e5da.pdf

13. Faludi AA, Izar MCO, Saraiva JFK, Chacra APM, Bianco HT, Afiune Neto A, et al.; Sociedade Brasileira de Cardiologia, Sociedade Brasileira de Diabetes, Sociedade Brasileira de Endocrinologia e Metabologia. Atualização da Diretriz Brasileira de Dislipidemias e Prevenção da Aterosclerose - 2017. Arq Bras Cardiol [Internet]. 2017;109(2Supl.1):176. Available from: http://www.scielo.br/pdf/abc/v109n2s1/0066-782X abc-109-02-s1-0001.pdf

14. Freitas LC, Rodrigues GM, Araújo FC, Falcon EBS, Xavier NF, Lemos ELDC, et al. Profile of hypertensive patients from Family Health Unit of Cidade Nova 8, city of Ananindeua-Pará, Brazil. Rev Bras Med Fam Comunidade [Internet]. 2012 Jan/Mar;7(22):13-9. Available from: http:// dx.doi.org/10.5712/rbmfc7(22)288

15. Moroz MB, Kluthcovsky ACGC, Schafranski MD. Blood pressure control in hypertensive elderly women attended in a Family Health Unit and associated factors. Cad Saúde Coletiva [Internet]. 2016 Jan/Mar;24(1):111-7. Available from: http://www.scielo.br/scielo. php?script=sci_arttext\&pid=S1414-462X2016000100111

16. Wong ND, Patao C, Wong K, Malik S, Franklin SS, lloeje U. Trends in control of cardiovascular risk factors among US adults with type 2 diabetes from 1999 to 2010: Comparison by prevalent cardiovascular disease status. Diab Vasc Dis Res [Internet]. 2014 Nov;10(6):505-13. Available from: https://doi.org/10.1177/1479164113496828

17. Duclos M, Dejager S, Postel-Vinay N, di Nicola S, Quéré S, Fiquet B. Physical activity in patients with type 2 diabetes and hypertension insights into motivations and barriers from the MOBILE study. Vasc Health Risk Manag [Internet]. 2015 Jun;11:361-71. Available from: https://doi.org/10.2147/VHRM.S84832

18. Gato WE, Acquah S, Nsiah P, Opoku ST, Apenteng BA, Johnson BK. Blood pressure control, glycemic control, and dyslipidemia among healthy adults in the Cape Coast metropolis, Ghana. Diabetes Metab Syndr Clin Res Rev [Internet]. 2019 Jan/Feb;13(1):56-61. Available from: https://doi.org/10.1016/j.dsx.2018.08.020

19. Esperandio EM, Espinosa MM, Martins MSA, Guimarães LV, Lopes MAL, Scala LCN. Prevalence and factors associated with hypertension in the elderly from municipalities in the Legal Amazon region, MT, Brazil. Rev Bras Geriatr Gerontol [Internet]. 2013 Jul/Sep;16(2):481-93. Available from: http://dx.doi.org/10.1590/S1809-98232013000300007 
20. Almeida TSO, Fook SML, Mariz SR. Associação entre etilismo e subsequente Hipertensão Arterial Sistêmica: uma revisão sistemática. Rev Saúde Ciênc OnLine [Internet]. 2016;5(1):76-90. Available from: $\mathrm{http}: / / w w w . u f c g . e d u . b r / r e v i s t a s a u d e e c i e n c i a / i n d e x$. php/RSC-UFCG/article/view/328/229

21. Rosendo I, Santiago LM, Marques M. Characteristics Associated with Uncontrolled Blood Pressure Among Portuguese Primary Care Patients with Type 2 Diabetes. Acta Med Port [Internet]. 2017 Mar;30(3):197-204. Available from: https://www.ncbi.nlm.nih.gov/pubmed/28550829

22. Rückert IM, Maier W, Mielck A, Schipf S, Völzke H, Kluttig A, et al. Personal attributes that influence the adequate management of hypertension and dyslipidemia in patients with type 2 diabetes. Results from the DIAB-CORE Cooperation. Cardiovasc Diabetol [Internet]. 2012 Oct;11:120. Available from: https://www.ncbi.nlm.nih.gov/ pubmed/23035799

23. Oliveira-Filho AD, Barreto-Filho JA, Neves SJF, Lyra Junior DP. Association between the 8-item Morisky Medication Adherence Scale (MMAS-8) and Blood Pressure Control. Arq Bras Cardiol [Internet]. 2012 Jul;99(1):649-58. Available from: http://dx.doi.org/10.1590/ S0066-782X2012005000053

24. Mahmoudian A, Zamani A, Tavakoli N, Farajzadegan Z, FathollahiDehkordi F. Medication adherence in patients with hypertension: Does satisfaction with doctor-patient relationship work? J Res Med Sci [Internet]. 2017;22:48. Available from: http://dx.doi.org/10.4103/jrms. JRMS_205_16

25. Yang Q, Chang A, Ritchey MD, Loustalot F. Antihypertensive Medication Adherence and Risk of Cardiovascular Disease Among Older Adults: A Population-Based Cohort Study. J Am Heart Assoc [Internet]. 2017 Jun;6(6):pii:e006056. Available from: https://www.ncbi.nlm.nih.gov/ pubmed/28647688

26. Piette JD, Rosland AM, Silveira MJ, Hayward R, McHorney CA. Medication cost problems among chronically ill adults in the US: did the financial crisis make a bad situation even worse? Patient Prefer Adherence [Internet]. 2011 Apr;5:187-94. Available from: http://dx.doi. org/10.2147/PPA.S17363
27. Cimmaruta D, Lombardi N, Borghi C, Rosano G, Rossi F, Mugelli A. Polypill, hypertension and medication adherence:The solution strategy? Int J Cardiol [Internet]. 2018 Feb;252:181-6. Available from: https://doi. org/10.1016/j.ijcard.2017.11.075

28. Dib MW, Riera R, Ferraz MB. Estimated annual cost of arterial hypertension treatment in Brazil. Rev Panam Salud Publica [Internet] 2010;27(2):125-31. Available from: https://scielosp.org/pdf/rpsp/2010. v27n2/125-131/en

29. Marinho MGS, Cesse EAP, Bezerra AFB, Sousa IMC, Fontbonne A, Carvalho EF. Analysis of health care costs of patients with diabetes mellitus and hypertension in a public health reference unit in Recife Brazil. Arq Bras Endocrinol Metabol [Internet]. 2011 Aug;55(6):406-11 Available from: http://dx.doi.org/10.1590/S0004-27302011000600007

30. Soto PHT, Raitz GM, Bolsoni LL, Costa CKF, Yamaguchi MU, Massuda EM. Morbidity and hospitalization costs of chronic diseases for the Unified National Health System. Rev Rene [Internet].2015;16(4):567-75. Available from: http://dx.doi.org/10.15253/2175-6783.2015000400014

31. Ruilope LM, Chagas ACP, Brandão AA, Gómez-Berroterán R, Alcalá JJA, Paris JV, et al. Hypertension in Latin America: Current perspectives on trends and characteristics. Hipertens Riesgo Vasc [Internet] 2017 Jan/Mar;34(1):50-6. Available from: http://dx.doi.org/10.1016/j. hipert.2016.11.005

32. Jardim PCBV, Souza WKSB, Lopes RD, Brandão AA, Malachias MVB, Gomes MM, et al. I RBH - First Brazilian Hypertension Registry. Arq Bras Cardiol [Internet]. 2016 Aug;107(2):93-8. Available from: http://www.scielo.br/scielo.php?script=sci_arttext\&pid=S0066782X2016004100093

33. Souza CS, Stein AT, Bastos GAN, Pellanda LC. Blood Pressure Control in Hypertensive Patients in the "Hiperdia Program": A Territory-Based Study. Arq Bras Cardiol [Internet]. 2014;102(6):571-8. Available from: http://dx.doi.org/10.5935/abc.20140081

34. Gallan AS, McColl-Kennedy JR, BarakshinaT, Figueiredo B, Jefferies JG, Gollnhofer J, et al. Transforming community well-being through patients lived experiences. J Bus Res [Internet]. 2018 Dec. E-pub ahead-of-print. Available from: http://dx.doi.org/10.1016/j.jbusres.2018.12.029

\footnotetext{
a This article is an excerpt of the End-of-Graduation-Course Paper entitled "Risk factors associated with the blood pressure control in elderly hypertensive patients" presented in November 2017 at the undergraduate course in Nursing, Faculty of Ceilândia (FCE), University of Brasilia (UNB).
} 